\title{
Sodium and potassium allocation under drought stress in Atlas mastic tree (Pistacia atlantica subsp. mutica)
}

\author{
Payam Fayyaz, Elham Etemadi, Nasim Julaiee-Manesh, Roghayeh \\ Zolfaghari
}

Sodium and potassium ions have crucial roles in drought tolerant mechanisms of plants. In a pot experiment, seedlings of Pistacia atlantica subsp. mutica were cultivated in a silty clay soil $\left(K_{\mathrm{ex}}=21 \mathrm{mg} / \mathrm{l}, \mathrm{Na}_{\mathrm{ex}}=143 \mathrm{mg} / \mathrm{l}\right)$ and exposed to different levels of soil water content $(90,65$ and $45 \%$ FC). P. atlantica maintained leaf transpiration rate, and relative water content and cation $\left(\mathrm{Na}^{+}\right.$and $\mathrm{K}^{+}$) content of different organs under moderate water deficit (above permanent wilting point). At higher water shortage, the amount of transpiration rate and the relative water content of tissues were reduced, but the amount of $\mathrm{Na}^{+}$ and $\mathrm{K}^{+}$remained unaffected even under severe drought stress (below permanent wilting point). Generally, the amount of $\mathrm{K}^{+}$content in plant organism was higher than that of $\mathrm{Na}^{+}$. The amount of root to shoot $\mathrm{Na}^{+}$was higher than that of $\mathrm{K}^{+}$. Potassium contents of leaves and stems were positively related with transpiration rate, whereas $\mathrm{Na}^{+}$contents of roots and stems were positively related with root relative water content. Roots and stem of Atlas mastic tree seedlings exhibit high drought tolerance index for $\mathrm{Na}^{+}$and $\mathrm{K}^{+}$.

Keywords: Pistacia atlantica Desf., Univalent Cations, Physiological Traits, Ion Translocation, Water Deficit

\begin{abstract}
Introduction
Among the many physiological features by which plants cope with water shortage, maintaining cation uptake and mobility in different tissues plays many crucial roles to deal with water deficit. Monitoring of cation changes under soil water shortage is so important that it was recently used as a drought tolerance index for selecting cultivars (Achakzai 2007, 2008). Nutrients uptake and consequent cation translocation highly depend on transpiration stream (Greenway \& Kelpper 1969). Reduced root lateral growth can also restrict nutrient uptake. Potassium is
\end{abstract}

$\square$ Institut of Natural Resources and Environment, University of Yasouj, 7591874831 Yasouj (Iran)

@ Payam Fayyaz

(payamfayyaz@gmail.com)

Received: Nov 07, 2012 - Accepted: Nov 14, 2012

Citation: Fayyaz P, Etemadi E, JulaieeManesh N, Zolfaghari R, 2013. Sodium and potassium allocation under drought stress in Atlas mastic tree (Pistacia atlantica subsp. mutica). iForest 6: 90-94 [online 2013-0207] URL: http://www.sisef.it/iforest/ contents?id=ifor0856-005

Communicated by: Giustino Tonon the most abundant cation in higher plants and is involved primarily in osmotic-mediated cell expansion (Elumalai et al. 2002), protein synthesis, glycolytic enzyme activity, membrane permeability, photosynthesis, stomatal movement, drought resistance (Hopkins \& Hüner 2004) and tropism (Philippar et al. 1999). In contrast, sodium at elevated concentrations - usually more than $100 \mathrm{mM}$ has toxic effects on plants. Sodium has lower replacing power than $\mathrm{K}^{+}$as revealed from Hofmeister's cation sequence, higher affinity with anionic groups as the carboxyl groups of proteins (Vrbka et al. 2006) and generally impairs the positive roles of $\mathrm{K}^{+}$in living cells. Because of high frequency, similar valence electron in outer shell, similar hydrated ion radius and deficiency of high performance discriminating antiporters (Maathuis \& Amtmann 1999), $\mathrm{Na}^{+}$interferes in $\mathrm{K}^{+}$uptake and translocation. It can also enhance plant performance, being involved in osmotic regulation in vacuoles (Mengel \& Kirkby 2001, Maathuis \& Sanders 1993). This role of $\mathrm{Na}^{+}$is even more relevant under water deficit where total nutrient uptake is affected by decreasing soil water content and $\mathrm{Na}^{+}$toxicity is not an issue. Most of studies emphasize the necessity of reducing $\mathrm{Na}^{+}$under salt stress to maintain high $\mathrm{K}^{+} / \mathrm{Na}^{+}$ratio in the intracellular space (Maathuis \& Amtmann 1999). Although changing $\mathrm{K}^{+} / \mathrm{Na}^{+}$ratio is not the main concern under drought
Box 1 - List of Abbreviations.

- FC: Field capacity

- PWP: Permanent wilting point

- SWC: Soil water content

- RWC: Relative water content

- $\mathrm{Na}_{\mathrm{ex}}$ : Exchangeable sodium

- $\mathrm{K}_{\mathrm{ex}}$ : Exchangeable potassium

- CEC: Cation exchange capacity at pH 7

- OC: Total organic carbon

stress, increasing of this ratio can facilitate plant survival and development under this condition. Exposing six cultivars of sorghum seedlings to progressive water deficit reduced the content of these univalent cations both in root and shoot, whereas the amount of sodium increased and potassium remained constant in the roots of a drought tolerance cultivar (Achakzai 2007). Plants that are able to take more $\mathrm{K}^{+}$and maintain higher $\mathrm{K}^{+} / \mathrm{Na}^{+}$ ratio in the intracellular space, are able to ameliorate the negative effects of drought on water relations and organic and inorganic solute accumulation in different organs (Nandwal et al. 1998).

The genus Pistacia (Anacardiaceae), commonly known for the edible nuts of $P$. vera, has at least 11 species worldwide. $P$. atlantica Desf. is a wild pistachio species which produces mastic (an edible resin) and small edible nuts with high content of valuable essential oils (Barrero et al. 2005, Tzakou et al. 2007, Gourine et al. 2009). As a xerophyte species, $P$. atlantica is widely distributed from south-west Asia to north-west Africa (Zohary 1952) and has wide range of pharmacological (Benhammou et al. 2008), cosmetic and food consumptions at local and industrial scale. At least three subspecies cabulica (Stocks) Rech. F., kurdica (Zohary) Rech. F., and mutica (Fish and May) Rech. F. - have been identified so far (Khatamsaz 1988). Pistacia atlantica subsp. mutica is a predominant tree species in Irano-Turanian region and mostly distributed in altitude of 900-2800 m a.s.l. Contrary to importance, the physiological mechanisms to deal with water shortage, one of the main growth limiting factors in $P$. atlantica habitats, are poorly investigated. Benhassaini et al. (2012) noted that RWC of the plantlet leaves of $P$. atlantica subsp. atlantica remained unaffected up to 200 meq. $1^{-1} \mathrm{NaCl}+\mathrm{CaCl}_{2}$ and decreased at 400 meq..$^{-1}$. Some studies on $P$. terebinthus and $P$. lentiscus, two similar wild pistachio species, describe these species as a drought-avoider, water-spender plants (Levitt 1980) that sustain high stomatal conductance and leaf RWC under water shortage and typically cannot stand long under harsh conditions (Sakcali \& Ozturk 2004, Vilagrosa 2002). However by increasing water deficit, drought avoidance strategy of 
wild pistachio turns towards water saving mechanisms by decreasing stomatal conductance and sap flow (Chirino et al. 2011, Vilagrosa 2002). Despite many progress, our current knowledge about drought tolerance strategies, especially in woody plants, is not comprehensive. In this paper, the behavio of Atlas mastic tree ( $P$. atlantica) seedlings under water deficit condition is investigated, with emphasis on altering univalent cations content and translocation in different organs. Also the relationship with leaf transpiration rate and relative water content of different organs is discussed. Finally drought tolerance indexes for $\mathrm{Na}^{+}$and $\mathrm{K}^{+}$accumulation in different tissues of $P$. atlantica are compared and discussed.

\section{Materials and methods}

\section{Plant preparation and treatments}

The experiment was conducted using 36,3 year-old saplings of $P$. atlantica Desf. subsp. mutica (Fisch. \& C. A. Mey.) Rech. f. (about $30 \mathrm{~cm}$ height and $4 \mathrm{~mm}$ collar diameter) under a plastic greenhouse in uncontrolled climatic condition in Yasouj (also Romanized as Yasuj and Yasooj), the center of "Kohgiluyeh and Boyer-Ahmad" province in Iran (30 40 '06" $\mathrm{N}, 51^{\circ} 35^{\prime} 17^{\prime}$ " E), during summer 2010. In February 2010, plants were obtained from Yasouj nursery and transferred into 3-liter pots (15 cm diameter) containing $80 \%$ field soil and $20 \%$ humus (sand $11 \%$, silt $45 \%$, clay $44 \%$, $\mathrm{pH} 7.9, \mathrm{~K}_{\mathrm{ex}} 21$ $\mathrm{mg} / \mathrm{l}, \mathrm{Na}_{\text {ex }} 143 \mathrm{mg} / \mathrm{l}$, CEC $2.5 \%$, OC $7.8 \%$ ) and divided into four groups with similar amount of leaves per group. Whole plants were irrigated 2-3 times per week until the beginning of experiment. Prior to experiment onset, soil moisture characteristics including field capacity and permanent wilting point were determined by pressure-plate apparatus (Richards 1947). Soil water content at 0.33 atm. (FC) and $15 \mathrm{~atm}$. (PWP) was 28.75\% and $15.95 \% \mathrm{w} / \mathrm{w}$, respectively (PWP 55\% of FC - Fig. 1).

The experiment started on July $20^{\text {th }}$ with controlled irrigation to reach the desired percentage of soil field capacity i.e., 90, 65 and $45 \%$. The average value of meteorological parameters together with $95 \%$ confidence interval during the experiment were as follow: $\operatorname{PAR}($ 9:00 am - 3:00 pm) $=1270 \pm 39 \mu \mathrm{mol}$ $\mathrm{m}^{-2} \mathrm{~s}^{-1}$; hours of sunshine $=11.2 \pm 0.5 \mathrm{~h} ; \mathrm{T}_{\max }$ $=39 \pm 0.5{ }^{\circ} \mathrm{C} ; \mathrm{T}_{\min }=18 \pm 0.5^{\circ} \mathrm{C}$; pan evaporation rate $=11.6 \pm 0.9 \mathrm{~mm} /$ day; relative humidity at 09:00 am $=24.6 \pm 5.2 \%$. The desired soil water content level was achieved after 12 days of water holding and plants were kept in these conditions for 4 further days.

\section{Transpiration rate and relative water content}

One day before harvest, transpiration rate of the youngest fully developed leaf of the plants was measured using a portable IRGA instrument (ADC LCA4 Bioscientific, United Kingdom) from 9:30 to 11:30 am on a full-sun day $\left(1270 \mu \mathrm{mol} \mathrm{m} \mathrm{m}^{-2} \mathrm{~s}^{-1} \mathrm{PAR}, 42^{\circ} \mathrm{C}\right.$ chamber temperature). Seven leaves per treatment were measured within 2 hours. After determining real leaf area in chamber using ImageJ software (Rasband 1997), area correction coefficient was applied to calculate corrected leaf transpiration rate. To determine relative water content (RWC), nearly 0.1-0.2 g of different tissues (leaf, stem and root) were weighed to accuracy of $0.001 \mathrm{~g}$ (FW) by a digital balance (GF-400, A\&D, Japan) and floated in distilled water for $24 \mathrm{~h}$ at room temperature in a dark place. Then samples were blotted by a tissue paper to measure the turgid weight (TW) and oven dried for $48 \mathrm{~h}$ at $80{ }^{\circ} \mathrm{C}$ to determining the dry weight (DW). Finally, RWC was calculated as follows (eqn. 1 - Barrs 1968):

$$
R W C(\%)=\frac{(F W-D W)}{(T W-D W)} \cdot 100
$$

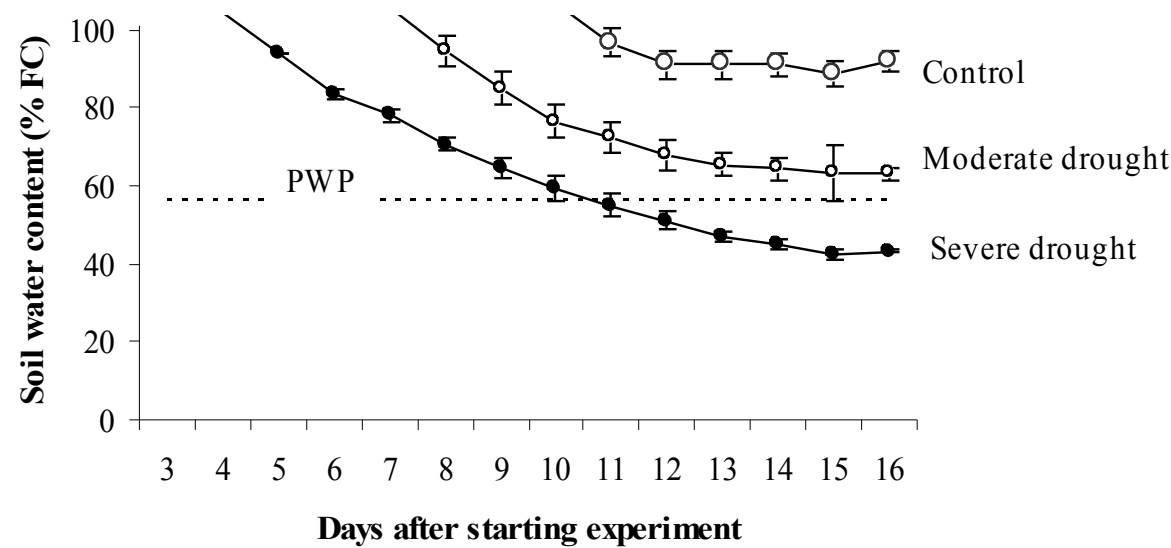

Fig. 1 - Kinetics of soil water content, expressed as percent of water content at field capacity, under different irrigating regimes. A dash line shows the permanent wilting point (PWP). Each point represents the mean of 12 observation \pm SE.

\section{Element analysis}

The concentration of $\mathrm{Na}^{+}$and $\mathrm{K}^{+}$in different organs (leaf, stem and root) was determined by dry ashing followed by photometric analysis (Ryan et al. 2007). A pool of three plant tissues was replicated 4 times per each water treatment. About $0.1 \mathrm{~g}$ of dried tissues was ashed in an oven at $500{ }^{\circ} \mathrm{C}$ for 7 h. Samples were then dissolved in $1 \mathrm{ml} 2 \mathrm{~N}$ $\mathrm{HCl}$ and diluted up to $10 \mathrm{ml}$ using distilled water. After filtration, the concentrations of $\mathrm{Na}^{+}$and $\mathrm{K}^{+}$were determined using flame photometer (Jenway PFP7, UK).

\section{Drought tolerance index}

Drought tolerance index (DTI) for cation accumulation $\left(\mathrm{Na}^{+}\right.$and $\mathrm{K}^{+}$separately and simultaneously) in different organs were calculated on the basis of Achakzai (2007, 2008) with some modifications as follows (eqn. 2):

$$
D T I=100 \cdot \frac{\operatorname{Ind}\left(C A_{\text {drought }}\right)}{\operatorname{Avg}\left(C A_{\text {control }}\right)}
$$

where $\operatorname{Ind}\left(C A_{\text {drougth }}\right)$ is the individual cation accumulation under severe drought (\%) and $\operatorname{Avg}\left(C A_{\text {control }}\right)$ is the average of cation accumulation under control conditions (\%). In order to achieve within group variations, DTI was calculated by dividing the cation content of each pool of plants standing under severe drought condition, by an average value of cation accumulation under control condition.

\section{Statistical analysis}

Determination of transpiration rate and relative water content were obtained from 7 plants for each treatment and a one-way analysis of variance was applied to evaluate the effect of water shortage treatments on these parameters. In the case of element analysis, four pools from each water regimes and different organs (leaf, stem and root) were measured and a two-way analysis of variance was performed to assess the main and interaction effects of water regime and organ type. A bivariate correlation analysis was performed to illustrate the relationship between desired traits. Also, a partial correlation analysis was conducted to evaluate the changes in the root and stem univalent cations $\left(\mathrm{Na}^{+}\right.$and $\left.\mathrm{K}^{+}\right)$by controlling either the leaf $\mathrm{Na}^{+}$or $\mathrm{K}^{+}$content. Drought tolerance indexes for cations accumulation were measured in four pools of plants underling severe water deficit level from each organ and a one-way analysis of variance was conducted to determine the effect of organ type on DTI for different cation accumulation. The putative outliers were found by drawing box-and-whisker plots, and values more than 3 folds of standard deviation from the mean were discarded. The analysis of variance was performed by applying a general linear model (GLM) and different levels of water defi- 


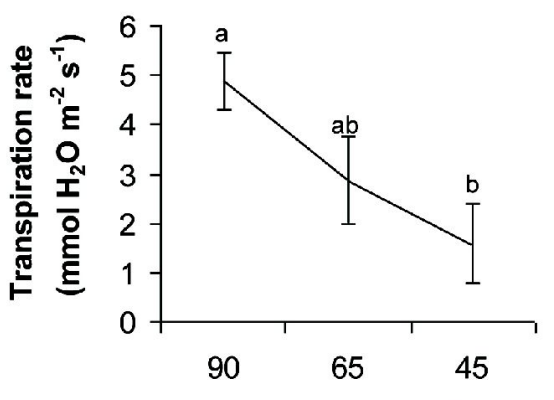

SWC (percent of FC)

Fig. 2 - Leaf transpiration rate in $P$. atlantica seedlings as a function of soil water shortage. Each point represents the mean of 7 observations \pm SE. Different letters indicate significant differences between means after Duncan's test $(\alpha=0.05)$.

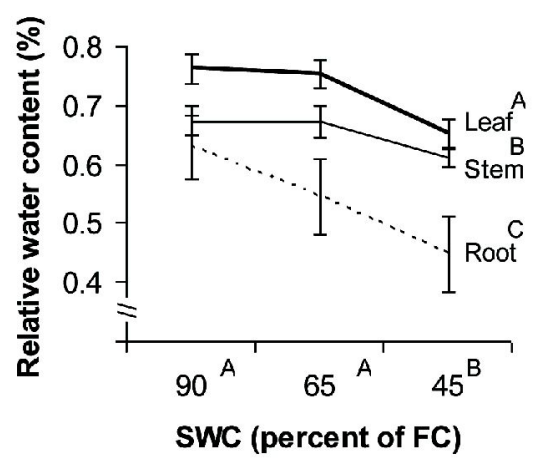

Fig. 3 - Relative water content of different tissues in $P$. atlantica seedlings as a function of soil water shortage. Each point represents the mean of 7 observations \pm SE. Different letters indicate significant differences between means after Duncan's test $(\alpha=0.05)$.

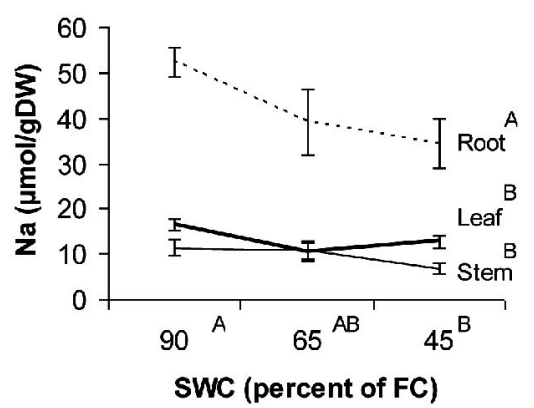

Fig. 4 - Sodium concentration in different tissues of $P$. atlantica seedlings as a function of soil water shortage. Each point represents the mean of 4 observations \pm SE. Different letters indicate significant differences between means after Duncan's test $(\alpha=0.05)$.

Tab. 1 - Pearson's correlation coefficients and significance levels obtained comparing leaf transpiration rate (E), relative water content (RWC) and ion contents of different organs, and soil water content (SWC $-\mathrm{n}=12) .\left({ }^{*}\right)$ : $\mathrm{p}<0.05 ;(* *)$ : $\mathrm{p}<0.01$.

\begin{tabular}{|c|c|c|c|c|c|c|c|c|c|c|}
\hline \multirow[t]{2}{*}{ Parameters } & \multicolumn{3}{|c|}{$\begin{array}{c}\text { Relative } \\
\text { water content }\end{array}$} & \multicolumn{3}{|c|}{$\begin{array}{c}\mathrm{K}^{+} \text {content } \\
(\mu \mathrm{mol} / \mathrm{gDW})\end{array}$} & \multicolumn{3}{|c|}{$\begin{array}{l}\mathrm{Na}^{+} \text {content } \\
(\mu \mathrm{mol} / \mathrm{gDW})\end{array}$} & \multirow{2}{*}{$\begin{array}{r}\text { SWC } \\
-(\% \mathrm{FC})\end{array}$} \\
\hline & Leaf & Stem & Root & Leaf & Stem & Root & Leaf & Stem & Root & \\
\hline $\mathrm{E}\left(\mathrm{mmol} \mathrm{H} \mathrm{H}_{2} \mathrm{O}^{-2} \mathrm{~s}^{-1}\right)$ & 0.24 & $0.41-$ & -0.19 & $0.63^{*}$ & $0.71 *$ & 0.21 & 0.33 & -0.12 & 0.02 & 0.52 \\
\hline Leaf RWC & - & $0.75 * *$ & 0.39 & 0.34 & 0.41 & 0.02 & -0.28 & 0.45 & 0.25 & $0.67 *$ \\
\hline Stem RWC & - & - & 0.19 & 0.44 & $0.70^{*}$ & 0.00 & -0.22 & -0.03 & -0.01 & 0.42 \\
\hline Root RWC & - & - & - & -0.20 & -0.02 & -0.10 & 0.11 & $0.72 *$ & $0.75 * *$ & 0.53 \\
\hline
\end{tabular}

Tab. 2 - Tolerance index (DTI) as percentage of drought-induced reduction in cation content in different organs of $P$. atlantica seedlings. Each group represents the mean of 4 observation \pm SE. Different letters in each column indicate significant differences with $95 \%$ confidence intervals after Duncan's multiple mean comparison.

\begin{tabular}{lccc}
\hline \multirow{2}{*}{ Organs } & \multicolumn{3}{c}{ Drought Tolerance Index (\%, Mean $\pm \mathbf{S E})$} \\
\cline { 2 - 4 } & $\mathbf{N a}^{+}$ & $\mathbf{K}^{+}$ & $\mathbf{N a}^{+}$and $\mathbf{~ K}^{+}$ \\
\hline Leaf & $77.26 \pm 5.5^{\mathrm{a}}$ & $46.44 \pm 3.0^{\mathrm{b}}$ & $50.05 \pm 3.0^{\mathrm{b}}$ \\
Stem & $57.46 \pm 10.1^{\mathrm{a}}$ & $82.05 \pm 8.8^{\mathrm{a}}$ & $80.94 \pm 8.4^{\mathrm{a}}$ \\
Root & $66.80 \pm 10.8^{\mathrm{a}}$ & $96.72 \pm 8.0^{\mathrm{a}}$ & $92.45 \pm 7.5^{\mathrm{a}}$ \\
\hline
\end{tabular}

cit were considered as a fixed effect variable in the model. Tests of normality and equality of variances of the residuals were conducted by Kolmogorov-Smirnov (with Lilliefors significance correction) and Levene's test. A natural logarithm transformation was applied for sodium concentration data. Differences of means were tested by Duncan's multiplerange test. Differences were considered statistically significant based on an alpha level of 0.05. All statistical analyses were performed using IBM SPSS Statistics 19 software (SPSS Inc., Chicago, IL, USA).

\section{Results}

Decreasing soil water content from 90 to $45 \%$ of FC gradually diminished transpiration rate of the seedlings of $P$. atlantica from 5 to $2 \mathrm{mmol} \mathrm{H}_{2} \mathrm{O} \mathrm{m}^{-2} \mathrm{~s}^{-1}$, but the amount of transpiration rate under $65 \%$ of $\mathrm{FC}$ did not change significantly (Fig. 2). Organ type and SWC affected RWC, but no significant interaction was observed between these factors. In all water regimes, the amount of RWC in $P$. atlantica increased from roots to leaves (Fig. 3). Regardless of the organ type, RWC of seedlings remained constant up to $65 \%$ of FC and decreased under severe drought condition $(45 \%$ of FC).

The univalent cations, $\mathrm{Na}^{+}$and $\mathrm{K}^{+}$, showed different patterns of allocation and response to drought in seedlings of $P$. atlantica $\mathrm{Na}^{+}$ ions mostly accumulated in roots and their concentration in both leaves and stems were at the lowest level (Fig. 4). $\mathrm{K}^{+}$ions had more free move than $\mathrm{Na}^{+}$ions from root to the aerial parts of the plant (Fig. 5). Also, $\mathrm{K}^{+}$content remained constant during water deficit conditions, while concentration of $\mathrm{Na}^{+}$decreased under severe water deficit.

Simple correlation analysis between soil water content, transpiration rate, relative water content and sodium and potassium content of different organs illustrated that transpiration increased with increasing leaf and stem $\mathrm{K}^{+}$content (Tab. 1). Also a positive correlation was observed between root RWC and $\mathrm{Na}^{+}$content of root and stem. Transpiration was not affected by the RWC of different organs (Tab. 1). The results of partial correlation analysis revealed that the part of root and stem $\mathrm{K}^{+}$content, that is not related with leaf $\mathrm{K}^{+}$content, was not related with RWC and transpiration. In contrast, the part of root $\mathrm{Na}^{+}$content that is independent from leaf $\mathrm{Na}^{+}$content was still highly and positively correlated with root relative water content $(r=0.791, p=0.006)$.

DTI for potassium accumulation was lower in the leaves than in the stem and roots, but DTI for sodium accumulation in different organs did not vary (Tab. 2). Considering both $\mathrm{Na}^{+}$and $\mathrm{K}^{+}$simultaneously resulted in a re-

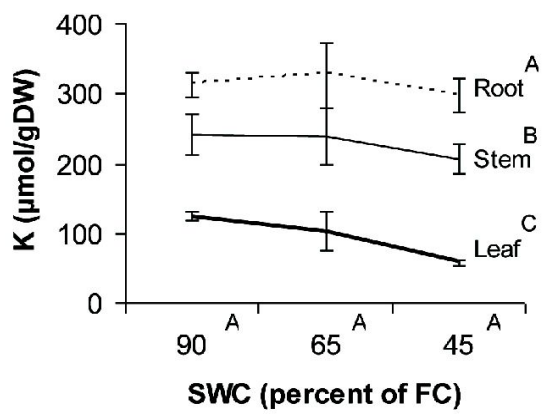

Fig. 5 - Potassium concentration in different tissues of $P$. atlantica seedlings as a function of soil water shortage. Each point represents the mean of 4 observations \pm SE. Different letters indicate significant differences between means after Duncan's test $(\alpha=0.05)$. 
sponse similar to that obtained by considering $\mathrm{K}^{+}$only. Performing multiple comparisons revealed that leaves of $P$. atlantica seedlings had lower DTI for $\mathrm{K}^{+}$and conjugated univalent cations $\left(\mathrm{Na}^{+}\right.$and $\left.\mathrm{K}^{+}\right)$than roots and stems (Tab. 2).

\section{Discussion}

In this study we demonstrated that seedlings of $P$. atlantica maintain a high level of transpiration and relative water content of different organs under moderate water deficit conditions $(65 \% \mathrm{FC})$ and decrease transpiration and RWC under severe stress ( $45 \%$ FC) These results confirm the two-step droughtavoider mechanisms of water spending and saving in $P$. atlantica as reported for $P$. terebinthus and $P$. lentiscus (Chirino et al. 2011, Vilagrosa 2002). Despite of relatively low soil exchangeable potassium availability for seedlings in this experiment $\left(\mathrm{K}_{\mathrm{ex}}=21 \mathrm{mg} / \mathrm{l}\right)$, $\mathrm{K}^{+}$content remained constant during soil water depletion. $\mathrm{K}^{+}$levels in root, stem and leaf were about 15, 10 and 5 times higher than that of the soil medium, respectively. The ability of $P$. atlantica to transport considerable amount of $\mathrm{K}^{+}$to the shoots and enhancing $\mathrm{K}^{+}$content of soil surface has been previously reported by Hosseini et al. (2012) Constant $\mathrm{K}^{+}$levels in different organs even under both $\mathrm{K}^{+}$deficit conditions and dropping of transpiration stream suggests the presence of high efficient $\mathrm{K}^{+}$uptake and transport mechanisms in $P$. atlantica. $P$. atlantica might benefit from some highly specific $\mathrm{K}^{+}$channels such as Shaker-type $\mathrm{K}^{+}$ channel (Heginbotham \& MacKinnon 1993) and SKOR (Stelar $\mathrm{K}^{+}$Outward Rectifier Latorre et al. 2003). Also, some proteins like CIPKs (Calcineurin B-like proteins interacting protein kinases) that regulate stomatal closure and $\mathrm{K}^{+}$uptake under drought conditions could be involved (Cheong et al 2007). In P. atlantica $\mathrm{K}^{+}$content was 5 to 10 times higher than that of $\mathrm{Na}^{+}$, indicating highly distinct absorption pathway with different efficiency for $\mathrm{K}^{+}$and $\mathrm{Na}^{+}$as reported for other plants (Lazof \& Cheeseman 1988). Also the stem to root $\mathrm{K}^{+}$content was 0.7 , whereas this ratio for $\mathrm{Na}^{+}$was lower (about 0.2 ). This result supports the conclusion that the rate of $\mathrm{Na}^{+}$translocation from root to shoot was more limited than that of $\mathrm{K}^{+}$. Restricting $\mathrm{Na}^{+}$transport, especially in stems, maintains a negative charge and facilitates $\mathrm{K}^{+}$entrance.

Regulation of $\mathrm{K}^{+}$transport in leaves affects cell turgidity, stomatal conductance, photosynthesis, cell expansion and oxidative metabolism (Marschner 1995). $\mathrm{K}^{+}$channels of guard cells have an important role in drought-induced stomatal closure (Laun 2002, Shabala 2003). $\mathrm{K}^{+}$content of leaves and stems of $P$. atlantica were positively correlated with transpiration rate, but no correlation was observed between $\mathrm{K}^{+}$content of root and transpiration. Some studies suggested that $\mathrm{K}^{+}$contents in roots and shoots are independent, so that shoot $\mathrm{K}^{+}$content is correlated with transpiration, while variations in root $\mathrm{K}^{+}$content is not in relation with leaf transpiration rate (Bowling \& Weatherley 1965). Plants containing high amount of $\mathrm{K}^{+}$ are able to absorb more water under drought stress (El-Hadi et al. 1997). Generally, in the early stages of drought stress the amount of $\mathrm{K}^{+}$uptake increases and finally declines at higher drought stress (Eavis 1972, Gerakis et al. 1975). Comparing DTI for $\mathrm{Na}^{+}$and $\mathrm{K}^{+}$accumulation (separately and simultaneously) suggested higher sensitivity of the leaves than of the stems and roots of Atlas mastic tree to water deficit, mostly due to restriction of $\mathrm{K}^{+}$transport into the leaves. The DTI for $\mathrm{K}^{+}$accumulation in leaves of $P$. atlantica (about $46 \%$ ) is in agreement with cultivars of sorghum (about 50\%) and maize (about $25 \%)$ as reported by Achakzai $(2007,2008)$. DTI for $\mathrm{K}^{+}$in $P$. atlantica roots $(96 \%)$ was higher than that in cultivars of sorghum (about 50\%) and maize (about 65\% - Achakzai 2007,2008$)$. In conclusion, $P$. atlantica is able to maintain high $\mathrm{K}^{+}$and $\mathrm{Na}^{+}$affinity even under low soil water and $\mathrm{K}^{+}$content. This behavior of $P$. atlantica is so marked that in natural forests, concentration of $\mathrm{K}^{+}$ and $\mathrm{Na}^{+}$in soil surface decreases with distance from the tree base (Hosseini et al. 2012).

$P$. atlantica showed both water-spending and water-saving strategies to deal with soil water depletion. Sodium and potassium accumulation and translocation were highly efficient and segregated. Transpiration and water content of shoots were positively correlated with $\mathrm{K}^{+}$content of shoots, whereas root RWC was affected by $\mathrm{Na}^{+}$content of root and stem. To increase drought tolerance of $P$. atlantica plantations, it is recommended to select varieties able to uptake more $\mathrm{Na}^{+}$ and $\mathrm{K}^{+}$. It can be also concluded that application of $\mathrm{K}^{+}$fertilizer can reduce drought damage to $P$. atlantica seedlings located in plantation and natural forests.

\section{Acknowledgments}

PF supervised the experimental design, performed the statistical analysis and drafted the manuscript, EE carried out the element analysis, NJ conducted the experiment, RZ contributed as advisor. We thank general director of Natural Resources and Watershed Management of Kohgiluyeh-and-Boyer-Ahmad Province for providing seedlings of $P$. atlantica. We wish also to express our thanks to Drs. H.R. Owliaie and M. Sedghi (Department of soil sciences, Yasouj University, Iran) for their help in measuring field capacity and physico-chemical characteristics of soil. This work is a part of a master student project that was financially supported by Yasouj University (Iran).

\section{References}

Achakzai AKK (2007). Effect of water potential on uptake and accumulation of cations by Sorghum seedlings. Journal of the Chemical Society of Pakistan 29: 321-327.

Achakzai AKK (2008). Effect of water potential on uptake and accumulation of cations by Maize seedlings (Zea mays L.). Journal of the Chemical Society of Pakistan 30: 271-275.

Barrero AF, Herrador MM, Arteaga JF, Akssira M, Mellouki F, Belgarrabe A, Blaquez MA (2005). Chemical composition of the essential oils of Pistacia atlantica Desf. Journal of Essential Oil Research 17: 52-54. - doi: 10.1080/ 10412905.2005.9698828

Barrs HD (1968). Determination of water deficits in plant tissue. In: "Water deficits and plant growth" (Kozlowski TT ed). Academic Press, New York, USA, pp. 235-368.

Benhammou N, Bekkara FA, Panovska TK (2008). Antioxidant and antimicrobial activities of the Pistacia lentiscus and Pistacia atlantica extracts. African Journal of Pharmacy and Pharmacology 2: 22-28.

Benhassaini H, Fetati A, Hocine AK, Belkhodja $M$ (2012). Effect of salt stress on growth and accumulation of proline and soluble sugars on plantlets of Pistacia atlantica Desf. subsp. atlantica used as rootstocks. Biotechnology, Agronomy, Society and Environment 16 (2): 159-165. Bowling DJF, Weatherley PE (1965). The relationships between transpiration and potassium uptake in Ricinus communis. The Journal of Experimental Botany 16: 732-741. - doi: 10.1093/ $\mathrm{jxb} / 16.4 .732$

Cheong YH, Pandey GK, Grant, JJ, Batistic O, Li L, Kim BG, Lee SC, Kudla J, Luan S (2007). Two calcineurin B-like calcium sensors, interacting with protein kinase CIPK23, regulate leaf transpiration and root potassium uptake in $\mathrm{Ara}$ bidopsis. The Plant Journal 52: 223-239. - doi: 10.1111/j.1365-313X.2007.03236.x

Chirino E, Bellot J, Sánchez JR (2011). Daily sap flow rate as an indicator of drought avoidance mechanisms in five Mediterranean perennial species in semi-arid southeastern Spain. Trees 25: 593-606. - doi: 10.1007/s00468-010-0536-4

Eavis BW (1972). Soil physical conditions affecting seedling root growth. I. Mechanical impedance. Aeration and moisture availability as influenced by bulk density and moisture levels in a sandy soil. Plant and Soil 36: 613-622. - doi: 10.1007/BF01373511

El-Hadi AHA, Ismail KM, El-Akabawy MA (1997). Effect of potassium on the drought resistance of crops in Egyptian conditions. In: Proceeding of the "Regional Workshop of IPI" (Johnston EA ed). Bornova (Izmir, Turkey) 2630 May 1997. IPI, Basel, Switzerland, pp. 328336.

Elumalai RP, Nagpal P, Read JW (2002). A mutation in the Arabidopsis KT2/KUP2 potassium transporter gene affects shoot cell expansion. The Plant Cell 14: 119-131. - doi: 10.1105/tpc. 010322

Gerakis PA, Guerrero FP, Williams WA (1975). 
Water relations and nutrition of three annuals as affected by drought. Journal of Applied Ecology 12: 125-136. - doi: 10.2307/2401722

Gourine N, Yousfi M, Nadjemi B, Bombarda I (2009). Chemical composition and antioxidan activity of essential oil of leaves of Pistacia atlantica Desf. from Algeria. Asian Journal of Chemistry 21: 1249-1257.

Greenway H, Kelpper B (1969). Relation between anion transport and water flow in tomato plants. Physiologia Plantarum 22: 208-219. - doi: 10.1111/j.1399-3054.1969.tb07857.x

Heginbotham L, MacKinnon R (1993). Conduction properties of the cloned Shaker $\mathrm{K}+$ channel. Biophysical Journal 65: 2089-2096. - doi: 10.1016/S0006-3495(93)81244-X

Hopkins WG, Hüner PA (2004). Introduction to plant physiology ( $3^{\text {rd }}$ edn). John Wiley and Sons Inc., USA, pp. 245.

Hosseini V, Akhavan R, Tahmasebi M (2012). Effect of Pistachio (Pistacia atlantica) canopy on the spatial distribution of soil chemical characteristics (case study: Sarvabad, Kurdistan). Iranian Journal of Forest 4: 13-24.

Khatamsaz M (1988). Flora of Iran No. 30: Anacardiaceae. Research Institute of Forests and Rangelands, Tehran, Iran.

Latorre R, Muñoz F, González C, Cosmelli D (2003). Structure and function of potassium channels in plants: some inferences about the molecular origin of inward rectification in KAT1 channels. Molecular Membrane Biology 20(1) 19-25. - doi: 10.1080/0968768021000057371

Laun S (2002). Signalling drought in guard cells. Plant, Cell and Environment 25: 229-237. - doi: 10.1046/j.1365-3040.2002.00758.x
Lazof D, Cheeseman J (1988). Sodium and potassium compartmentation and transport in the roots of intact Lettuce plants. Plant Physiology 88: 1279-1284. - doi: 10.1104/pp.88.4.1279

Levitt J (1980). Responses of plants to environmental stresses. In: "Water deficits and plant growth" (Kozlowski TT ed). Academic Press, New York, USA.

Maathuis FJM, Amtmann A (1999). K+ nutrition and $\mathrm{Na}+$ toxicity: the basis of cellular $\mathrm{K}+\mathrm{Na}+$ ratios. Annals of Botany 84: 123-133. - doi: 10.1006/anbo.1999.0912

Maathuis FJM, Sanders D (1993). Energization of potassium uptake in Arabidopsis thaliana. Planta 191: 302-307. - doi: 10.1007/BF001956 86

Marschner H (1995). Mineral nutrition of higher plants $\left(2^{\text {nd }} \mathrm{edn}\right)$. Academic Press, London, UK, pp. 889.

Mengel K, Kirkby E (2001). Principles of plant nutrition $\left(5^{\text {th }}\right.$ edn). Kluwer Academic Publishers, The Hague, The Netherlands, pp. 849.

Nandwal AS, Hooda A, Datta D (1998). Effect of substrate moisture and potassium on water relations and $\mathrm{C}, \mathrm{N}$ and $\mathrm{K}$ distribution in Vigna radiata. Biologia Plantarum 41: 149-153. - doi: 10.1023/A:1001745423649

Philippar K, Fuchs I, Lüthen H, Hoth S, Bauer CS, Haga K, Thiel G, Ljung K, Sandberg G, Böttger M, Becker D, Hedrich R (1999). Auxin-induced $\mathrm{K}+$ channel expression represents an essential step in coleoptile growth and gravitropism. Proceedings of the National Academy of Sciences USA 96 (21): 12186-12191. - doi: $10.1073 /$ pnas.96.21.12186

Rasband W (1997). ImageJ 1.43u. National Insti- tutes of Health, Bethesda, Maryland, USA. [online] URL: http://rsb.info.nih.gov/ij

Richards LA (1947). Pressure membrane apparatus construction and use. Journal of Agricultural Engineering Research 28: 451-454.

Ryan J, Estefan G, Rashid A (2007). Soil and plant analysis laboratory manual. ICARDA, Islamabad, Pakistan.

Sakcali MS, Ozturk M (2004). Eco-physiological behaviour of some mediterranean plants as suitable candidates for reclamation of degraded areas. Journal of Arid Environments 57: 141153. - doi: 10.1016/S0140-1963(03)00099-5

Shabala S (2003). Regulation of potassium transport in leaves: from molecular to tissue level. Annals of Botany 92: 627-634. - doi: 10.1093/ aob/mcg191

Tzakou O, Bazos I, Yannitsaros A (2007). Volatile metabolites of Pistacia atlantica Desf. from Greece. Flavour and Fragrance Journal 22: 358362. - doi: 10.1002/ffj. 1805

Vilagrosa A (2002). Strategies of resistance to water deficit in Pistacia lentiscus L. and Quercus coccifera L. implications reforestation. Ph.D. dissertation, Universidad de Alicante, Alicante, Spain.

Vrbka L, Vondrášek J, Jagoda-Cwiklik B, Vácha R, Jungwirth P (2006). Quantification and rationalization of the higher affinity of sodium over potassium to protein surfaces. Proceedings of the National Academy of Sciences USA 103. 15440-15444. - doi: 10.1073/pnas.0606959103

Zohary M (1952). A monographic study of the genus Pistacia. Palestine Journal of Botany 5: 187-228. 